\title{
Emergence of 'Genesis' Triploid Watermelon following Mechanical Scarification
}

\author{
John R. Duval ${ }^{1}$ and D. Scott NeSmith ${ }^{2}$ \\ Department of Horticulture, University of Georgia, Georgia Experiment Station, Griffin, GA 30223
}

\begin{abstract}
AdDitional INDEX words. Citrullus lanatus, seedless watermelon, seedlings, seedcoat adherence
Abstract. Production of triploid watermelon [Citrullus lanatus (Thunb.) Matsum \& Nakai] transplants is hindered by poor, inconsistent emergence, and frequent seed coat adherence to cotyledons. Seed coat adherence leads to weakened and slow growing plants. High seed costs, coupled with stand establishment problems, discourages transplant producers from growing this crop. Improvement of triploid watermelon emergence will lessen financial risks to growers and transplant producers and will provide a more reliable production system. Mechanical scarification was evaluated as a means to overcome inconsistent emergence and seed coat adherence. Seeds of ' $G$ enesis' triploid watermelon were placed in a cylinder with $100 \mathrm{~g}$ of very coarse sand (1.0 to $2.0 \mathrm{~mm}$ diameter) and rotated at $60 \mathrm{rpm}$ for $0,6,12,24$, and 48 hours in a series of experiments. Number of emerged seed was recorded daily, to obtain emergence dynamics. No significant differences were observed in seed coat adherence among treatments. The longest duration of scarification However, enhanced emergence as compared to the control in three of four experiments. These data support earlier suggestions that a thick or hard seed coat is a factor contributing to poor germination and emergence of triploid watermelons.
\end{abstract}

Today, specialty vegetables are gaining market prominence and triploid watermelons [Citrullus lanatus (Thunb.) Matsum \& Nakai] are an attractive option for consumers (Maynard and Elmstrom, 1992). Taste test and consumer interviews indicated a significant market growth potential for triploid or seedless watermelons (Marr and Gast, 1991) In addition, grower and breeder interest in seedless watermelons is increasing, in part, due to triploid watermelons' heightened resistance to nematodes (Montalvo and Esnard, 1994) and watermelon fruit blotch (Acidivorax avenae subsp. citrulli) (Garret et al., 1995). Although the potential exists for greater economic return from seedless watermelons (Marr and Gast, 1991), production remains low. Poor germination and emergence, slow growth in cool weather, and high seed costs are major limiting factors to increased production acreage. Research is needed to reduce the production risks associated with stand establishment of seedless watermelons.

Seedcoats often adhere to cotyledons after germination, preventing cotyledon expansion resulting in deformed seedlings that reduce the number of vigorous transplants. Orienting the radicle end up at $45^{\circ}$ or $90^{\circ}$, rather than with the radicle end down or on the horizontal can reduce seedcoat adherence (Maynard, 1989). Such a procedure is time consuming and labor intensive for transplant producers; therefore, a simpler method for decreasing seedcoat adherence is needed to make triploid watermelon transplant production more efficient and cost effective.

Triploid watermelon seeds arise from a tetraploid mother plant, which produces triploid seed with seedcoats having characteristics of the tetraploid mother (thick seedcoat) rather than the diploid parent (thin seedcoat) (Kihara, 1951). Mechanical scarification has been widely used to enhance seed germination of many tree and weed species. This procedure is used to remove physical barriers to water uptake and gas diffusion an in eliminates mechanical restriction of embryo growth (Zodape, 1991).

Received for publication 27 July 1998. Accepted for publication 29 Mar. 1999. A contribution of the University of Georgia Agricultural Experiment Station, Georgia Station, Griffin. This research was supported by state and Hatch Act funds allocated to the Georgia Agricultural Experiment Station. The cost of publishing this paper was defrayed in part by the payment of page charges. Under postal regulations, this paper therefore must be hereby marked advertisement solely to indicate this fact. ${ }^{1}$ Graduate student.

${ }^{2}$ Associate professor.
Scarification research to date has largely focused on weed, ornamental, and tree species due to a lack of seedcoat related problems in most vegetable crops. Nerson et al. (1985) indicated that significant improvements of germination could be obtained by laterally splitting the seedcoat (mechanical scarification) of the tetraploid watermelon 'Alena' and the triploid watermelon 'Tri$X$ X13'. This research was conducted to determine the effect of a simple, efficient, and cost effective method to weaken triploid watermelon seedcoats to reduce seedcoat adherence, and emergence of a triploid watermelon cultivar.

\section{Material and Methods}

A series of emergence experiments were conducted under controlled environments with 'Genesis' triploid watermelon. In each experiment, 130 seeds of 'Genesis' triploid watermelon were tumbled with $100 \mathrm{~g}$ of very coarse sand (1.0 to $2.0 \mathrm{~mm}$ in diameter) in a cylinder (Natural Science Industries, Hempstead, N.Y.) (depth $7 \mathrm{~cm}$, circumference $25 \mathrm{~cm}$ ) rotating at $60 \mathrm{rpm}$ for $0,6,12,24$, and $48 \mathrm{~h}$. Seeds were weighed before and after scarification to determine the amount of seedcoat material lost. Five groups of 20 seeds were separated from the total and 30 were set aside for later observation. One set of 20 seeds was considered a replication for the respective treatment. The experiments were conducted at $25^{\circ} \mathrm{C}, 30 / 20^{\circ} \mathrm{C}$ and $30 / 25^{\circ} \mathrm{C}$ alternating $12 \mathrm{~h}$ day/night temperatures to approximate greenhouse conditions. Seeds were planted in a completely randomized block design and were replicated 5 times at $25^{\circ} \mathrm{C}$ and $30 / 20^{\circ} \mathrm{C}$, and replicated 10 times at $30 / 25^{\circ} \mathrm{C}$. Seeds were placed horizontally at a uniform depth $(1.5 \mathrm{~cm})$ to remove any advantage due to seed orientation (Maynard, 1989). Planting flats (Foam Fabrication, Compton, Calif.) contained 200 inverted cone cells with a depth of $5.7 \mathrm{~cm}$ and a volume of $20 \mathrm{~cm}^{3}$. Metro-mix 300 (Scotts, Marysville, Ohio) was used as the growing media. Flats were placed in a growth chamber (modelE15; Conviron, Pembina, N.D.) with a 12/12-h day/ night cycle. Flats were thoroughly watered once each morning. Emergence and seedcoat adherence data were taken daily on each individual cell monitoring for $12 \mathrm{~d}$. A seed was considered emerged when cotyledons were completely raised above the media. Seed for all experiments came from the same lot. Seed viability was tested by removing the seedcoat and germinating embryos on agar. Viability was $>90 \%$ (data not shown). 


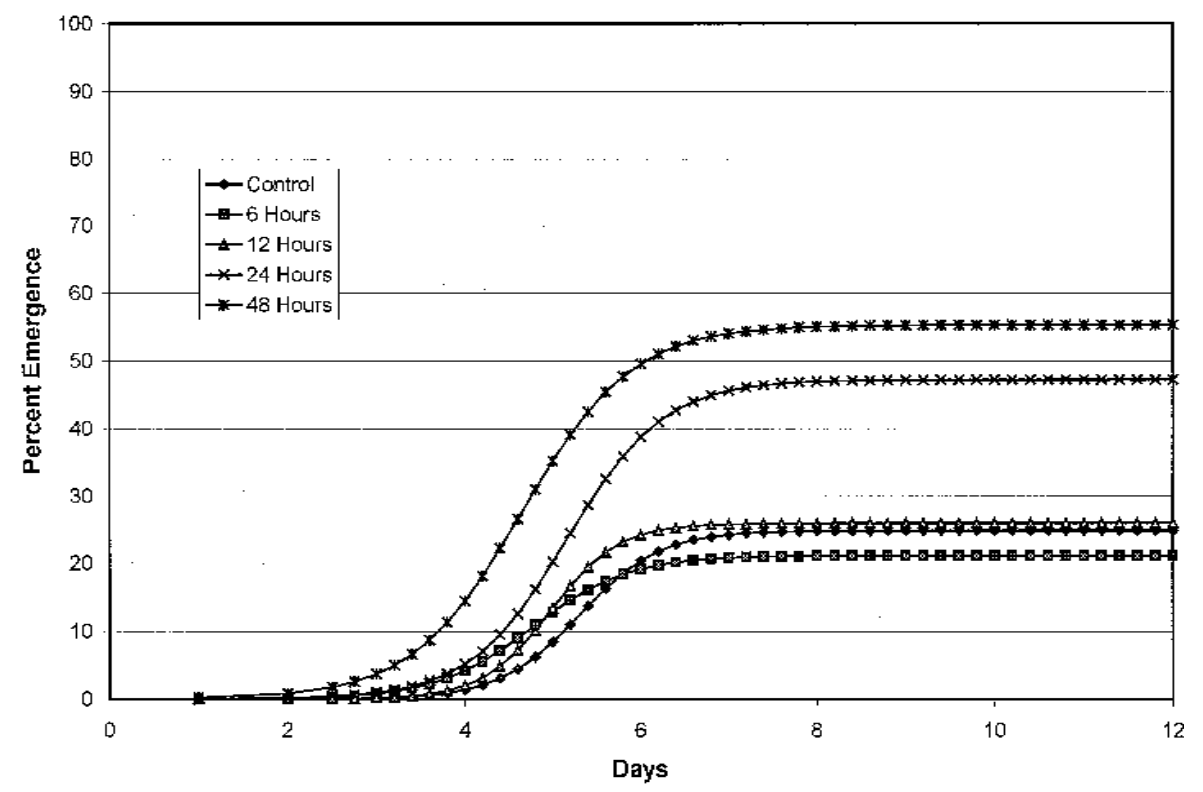

the 12 - or $24-\mathrm{h}$ treatments. In addition, the control reached $90 \%$ of its maximal emergence slower than the 6-, 12-, 24-, and 48-h treatments (Table 1).

\section{Discussion}

While the emergence percentages in these experiments are lower than those usually seen for 'Genesis' in a greenhouse, some useful information can be obtained from these results. Scarification for 24 to $48 \mathrm{~h}$ consistently provided higher final emergence of 'Genesis' triploid watermelon as compared to the unscarified control. Consistent results from a seed treatment is essential for transplant producers. It allows for an efficient use of resources, since the ability to estimate over seeding requirements is necessary to produce the desired number of plants.

As noted earlier, the seedcoat of a triploid seed is much thicker than a diploid seed, which

Fig. 1. Emergence of 'Genesis' triploid watermelon seeds mechanically scarified for $0,6,12,24$, and $48 \mathrm{~h}$ at $25^{\circ} \mathrm{C}$. Model parameter estimates can be found in Tble 1 .

Statistical data for time until seedcoat shedding and percent adherence were analyzed using ANOVA procedures. Emergence data was not transformed, emergence was modeled and analyzed using the following logistic function (SAS Institute, 1990):

$\mathrm{Y}=\beta_{0} /\left[(1+(1-\mathrm{p}) / \mathrm{p}) e^{-\beta^{1}\left(\mathrm{day}-\beta^{2}\right)}\right]$

where $\beta_{0}=$ Asymptote of final emergence percentage, $\beta_{1}=$ Relative rate of emergence, $\beta_{2}=$ Time until asymptote of $p$ is reached, $\mathrm{p}=$ point where a predetermined value of maximal emergence is obtained $(90 \%)$.

Significant differences between parameters was determined using $95 \%$ confidence intervals.

\section{Results}

Observation of scarified seeds revealed that the seedcoat was not affected by any treatment. Measurements of seedcoat material lost during scarification showed negligible amounts $(<0.1 \%)$ lost even after $48 \mathrm{~h}$ (data not shown). However, the radicle ends of the seeds showed considerable mechanical abrasion after $48 \mathrm{~h}$ of scarification.

Emergence for seeds scarified for $48 \mathrm{~h}$ exceeded that of all other treatments at $25{ }^{\circ} \mathrm{C}$ (Fig. 1). Scarification for $24 \mathrm{~h}$ also exceeded shorter duration treatments. No differences were noted in the rate of emergence or time to $90 \%$ of the asymptotic maximum emergence among treatments. Model parameter estimates can be found in Table 1 .

Emergence of seed scarified for $48 \mathrm{~h}$ was greater than other scarification treatments when emergence was measured at 30/25 ${ }^{\circ} \mathrm{C}$ (Fig. 2). Scarification for $48 \mathrm{~h}$ was not different from the control. Statistically, there were differences in time to $90 \%$ of maximal emergence (Table 1). However, these differences are not practically meaningful.

When emergence was conducted at $30 / 20^{\circ} \mathrm{C}$, the control and 6$\mathrm{h}$ scarification treatments had significantly lower final emergence than the treatments of longer scarification duration (Fig. 3). Emergence from seed scarified for $24 \mathrm{~h}$ was higher than that for the 12-h treatment. Emergence of seeds scarified for $48 \mathrm{~h}$ did not differ from possibly limits the passage of water or gases into the seed. When the seed is imbibed this further compounds the problem of oxygen diffusion by producing a thick continuous wet layer around the embryo through which oxygen must pass (Nerson et al., 1985). Weakening the seedcoat or the opening of small holes at the radicle end of the seed may facilitate movement of gases into the seed. Viability tests showed that when the seedcoat was removed, higher than reported germination percentages were obtained.

Seedcoat adherence was not affected by scarification (average of $44 \%$ adherence, average of $1.7 \mathrm{~d}$ to shedding). The scarification technique employed did not sufficiently weaken seedcoats to the point that they were shed easily. However, had seeds been scarified to a greater degree, perhaps this would have reduced

Table 1. Logistic model parameter estimates for emergence of 'Genesis' triploid watermelon after scarification and germination at various temperatures; $\beta_{0}$ is the asymptote of final emergence, $\beta_{1}$ is the relative rate of emergence, $\beta_{2}$ is the time until $90 \%$ of final emergence is reached.

\begin{tabular}{lcccc}
\hline \hline Scarification & & & & \\
hours & $\beta_{0}$ & $\beta_{1}$ & $\beta_{2}$ & $r^{2}$ \\
\hline & & \multicolumn{2}{c}{$\mathbf{2 5}^{\circ} \mathbf{C}$} & \\
0 & $24.8 \mathrm{a}^{\mathrm{z}}$ & $2.2 \mathrm{a}$ & $6.3 \mathrm{a}$ & 0.70 \\
6 & $21.1 \mathrm{a}$ & $1.8 \mathrm{a}$ & $6.0 \mathrm{a}$ & 0.50 \\
12 & $25.9 \mathrm{a}$ & $2.6 \mathrm{a}$ & $5.8 \mathrm{a}$ & 0.70 \\
24 & $47.2 \mathrm{~b}$ & $1.8 \mathrm{a}$ & $6.4 \mathrm{a}$ & 0.74 \\
48 & $55.3 \mathrm{c}$ & $1.6 \mathrm{a}$ & $6.0 \mathrm{a}$ & 0.79 \\
& & $\mathbf{3 0 / 2 5}{ }^{\circ} \mathbf{C}$ Day/Night & \\
0 & $58.7 \mathrm{ab}$ & $1.2 \mathrm{a}$ & $8.1 \mathrm{a}$ & 0.72 \\
6 & $54.9 \mathrm{a}$ & $1.1 \mathrm{a}$ & $7.7 \mathrm{bc}$ & 0.82 \\
12 & $53.4 \mathrm{a}$ & $1.1 \mathrm{a}$ & $7.9 \mathrm{ab}$ & 0.77 \\
24 & $54.9 \mathrm{a}$ & $1.0 \mathrm{a}$ & $8.1 \mathrm{a}$ & 0.75 \\
48 & $64.4 \mathrm{~b}$ & $1.1 \mathrm{a}$ & $7.5 \mathrm{c}$ & 0.74 \\
& & $30 / 20$ & $\mathbf{C}$ Day/Night & \\
0 & $16.1 \mathrm{a}$ & $1.07 \mathrm{a}$ & $9.6 \mathrm{c}$ & 0.81 \\
6 & $21.4 \mathrm{a}$ & $1.60 \mathrm{a}$ & $7.6 \mathrm{a}$ & 0.41 \\
12 & $37.0 \mathrm{~b}$ & $1.77 \mathrm{a}$ & $7.4 \mathrm{a}$ & 0.68 \\
24 & $46.6 \mathrm{c}$ & $1.29 \mathrm{a}$ & $8.0 \mathrm{~b}$ & 0.89 \\
48 & $42.4 \mathrm{bc}$ & $1.60 \mathrm{a}$ & $7.3 \mathrm{a}$ & 0.92
\end{tabular}

${ }_{\mathrm{z}}$ Means followed by the same letter are not statistically different $(P<0.05)$. 
Fig. 2. Emergence for 'Genesis' triploid watermelon seeds mechanically scarified for $0,6,12,24$, and $48 \mathrm{~h}$ at $30 / 25^{\circ} \mathrm{C}$. Model parameter estimates can be found in Table 1.

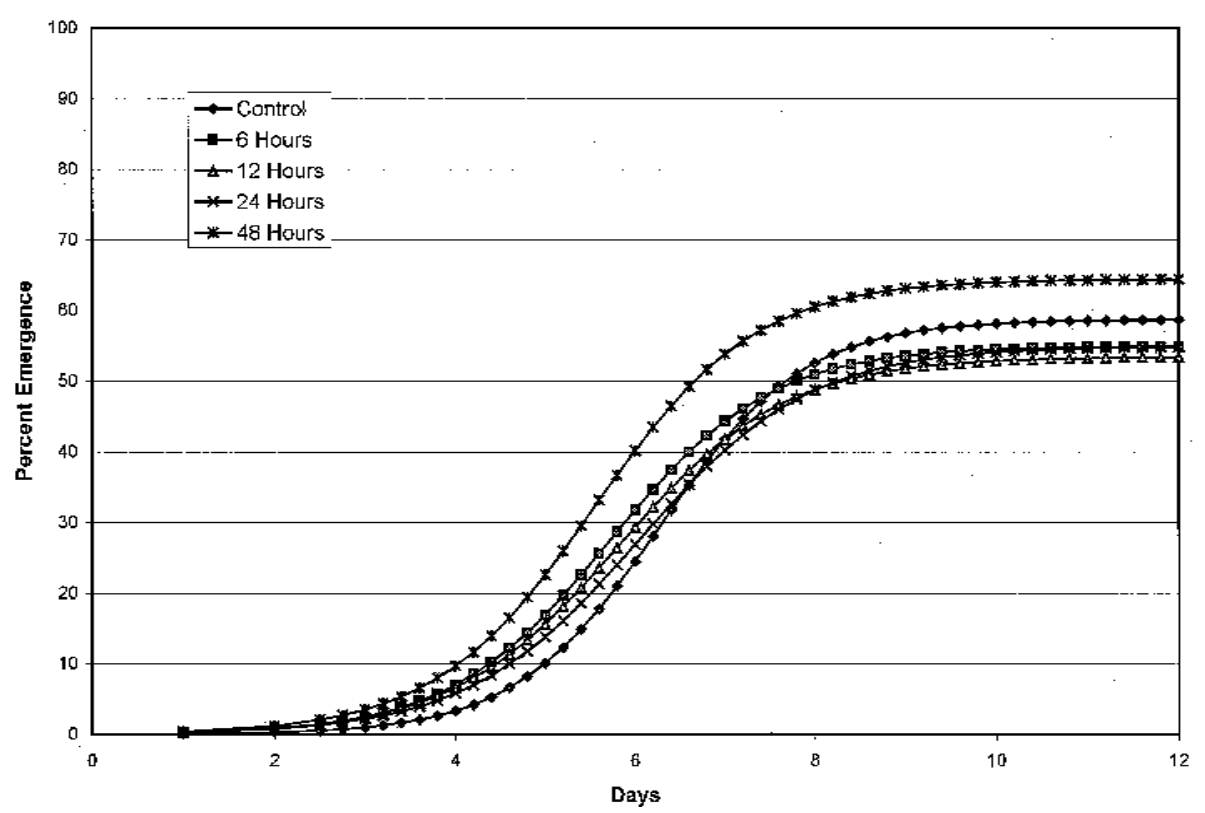

Fig.3. Emergence of 'Genesis' triploid watermelon seeds mechanically scarified for $0,6,12,24$, and $48 \mathrm{~h}$ at $30 / 20^{\circ} \mathrm{C}$. Model parameter estimates can be found in Table 1 .

seedcoat adherence to cotyledons following emergence.

Although percent emergence of 'Genesis' was low, especially for controls, such results are not uncommon. Kihara (1951) noted that improvement of triploid watermelon germination following seed treatments were inconsistent for the same treatment. Data from the current experiment indicate that scarification of triploid seedcoats results in more consistent emergence than unscarified seed. Further research is needed to determine the effect of the seedcoat on gas diffusion and water uptake.

\section{Literature Cited}

Kihara, H. 1951. Triploid watermelons. Proc. Amer. Soc. Hort. Sci. 58:217-230.

Garret, J.T., B.B. Rhodes, and Z. Xing-Ping. 1995. Triploid watermelons resist fruit blotch organism. Rpt. Cucurbit Genet. Coop. 18:56-57

Marr, C. and K.L.B. Gast. 1991. Reactions by consumers in a farmers' market to prices for seedless watermelon and ratings of eating quality. HortTechnology 1(1):105-106.

Maynard, D.N. 1989. Triploid watermelon seed orientation affects seedcoat adherence on emerged cotyledons. HortScience 24(4):603-604.
Maynard, D.N. and G.W. Elmstrom. 1992. Triploid watermelon production and practices. Acta Hort. 318:169-173.

Montalvo, A.E. and J. Esnard. 1994. Reaction of ten cultivars of watermelon (Citrullus lanatus) to a Puerto Rican population of Meloidogyne incognita. J. Nematol. 26(4S):640-643.

Nerson, H., H.S. Parks, Z. Karchi, and M. Sachs. 1985. Seed treatments for improved germination of tetraploid watermelon. HortScience 20(5):897-899.

SAS Institute. 1990. SAS user's guide: Statistics (6th ed.). SAS Inst., Cary, N.C.

Zodape, S.T. 1991. The improvement of germination of some forest species by acid scarification. Indian For. Jan. 61-65. 